\title{
Sialic acid-binding lectin (leczyme) induces caspase-dependent apoptosis-mediated mitochondrial perturbation in Jurkat cells
}

\author{
TAKEO TATSUTA ${ }^{1}$, MASAHIRO HOSONO ${ }^{1}$, SHIGEKI SUGAWARA ${ }^{1}$, YUKIKO KARIYA ${ }^{2}$, \\ YUKIKO OGAWA $^{3}$, SENITIROH HAKOMORI ${ }^{4}$ and KAZUO NITTA ${ }^{1}$ \\ ${ }^{1}$ Division of Cell Recognition Study, Institute of Molecular Biomembrane and Glycobiology, \\ Tohoku Pharmaceutical University, Aoba-ku, Sendai 981-8558; ${ }^{2}$ Fukushima Medical University, \\ Fukushima 960-1295; ${ }^{3}$ Divisions of Functional Morphology and Microbiology, Department of Pharmacy, \\ Faculty of Pharmaceutical Science, Nagasaki International University, Sasebo, Nagasaki 859-3298, Japan; \\ ${ }^{4}$ Division of Biomembrane Research, Pacific Northwest Research Institute, Seattle, WA 98122, USA
}

Received June 29, 2013; Accepted August 6, 2013

DOI: 10.3892/ijo.2013.2092

\begin{abstract}
Sialic acid binding lectin (SBL) isolated from Rana catesbeiana oocytes is a multifunctional protein which has lectin activity, ribonuclease activity and antitumor activity. However, the mechanism of antitumor effects of SBL is unclear to date and the validity for human leukemia cells has not been fully studied. We report here that SBL shows cytotoxicity for some human leukemia cell lines including multidrug-resistant (MDR) cells. The precise mechanisms of SBL-induced apoptotic signals were analyzed by combinational usage of specific caspase inhibitors and the mitochondrial membrane depolarization detector JC-1. It was demonstrated that SBL causes mitochondrial perturbation and the apoptotic signal is amplified by caspases and cell death is executed in a caspasedependent manner. The efficacy of this combinational usage was shown for the first time, to distinguish the apoptotic pathway in detail. SBL selectively kills tumor cells, is able to exhibit cytotoxicity regardless of P-glycoprotein expression and has potential as an alternative to conventional DNA-damaging anticancer drugs.
\end{abstract}

\section{Introduction}

Historically, replicative DNA was the main target of anticancer agents for many years, but because of the selectivity or occurrence of resistance to the drugs, agents which have new strategy such as molecular targeted therapy show promise for the treatment of cancer. Efforts to improve cancer therapy

Correspondence to: Dr Kazuo Nitta, Institute of Molecular Biomembrane and Glycobiology, Tohoku Pharmaceutical University, 4-4-1 Komatsushima, Aoba-ku, Sendai 981-8558, Japan

E-mail:knitta@tohoku-pharm.ac.jp

Key words: lectin, ribonuclease, antitumor effect, leczyme, Rana catesbeiana, caspase pathway, mitochondria perturbation have focused on the development of more selective, biological mechanism-based agents that can overcome tumor resistance, as well as minimize toxic effects to normal cells (1).

Ribonucleases are enzymes which catalyze the degradation of RNA. RNases display various biological roles, including nutritional function, remobilization of phosphate, senescence, self-incompatibility, defensin-like activity and the conspicuous function in RNA metabolism $(2,3)$. Some members of RNases are reported to exhibit angiogenic, neurotoxic, antitumor, or immunosuppressive activities (4). Bovine pancreatic ribonuclease A (RNase A), EC 3.1.27.5 (5), was the first RNase tested for a possible anticancer activity in vitro (6-8) and in vivo (9-12). While RNase A needed high amounts to observe the anticancer activity, more effective RNases have been reported in recent years. The proposed mechanism of ribonuclease-induced cytotoxicity is: i) cell surface binding and internalization, ii) translocation to the cytosol, iii) evasion of the cytosolic ribonuclease inhibitor protein (RI) and iv) degradation of cellular RNA. Differences in the efficiency of any of these steps could affect the cell susceptibility (13). One promising RNase for cancer therapeutic drug is onconase, a ribonuclease isolated from Rana pipiens oocytes. Onconase, manifests cytotoxic and cytostatic effects (14), presents synergism with several kinds of anticancer drugs (15-22) and at present is in phase II/III clinical trials as an anticancer drug $(1,23)$. Onconase has demonstrated some advantages for potential clinical applications, including: a) evading human RNase inhibitors in cytosol, b) inhibitory activity against broad types of human tumors, c) without any untoward immune response and exerting only weak and reversible renal toxicity (24). The phase III clinical trial of onconase has prompted the genetic engineering of known RNases as well as a search for new medicinal RNases $(3,12,24,25)$.

Sialic acid binding lectin (SBL) isolated from $R$. catesbeiana oocytes was found as a lectin, because SBL agglutinates various kinds of tumor cells and the agglutination was inhibited by sialoglycoprotein or ganglioside (26-28). Agglutination induced by SBL was observed in tumor cells, but not in normal 
red blood cells or fibroblasts (28). Amino acid sequence of SBL shows that it has homology to the member of RNase A superfamily and it has been revealed that SBL practically has pyrimidine base-specific ribonuclease activity (29-32). The antitumor effect of SBL was reported using P388 and L1210 murine leukemia cells in vitro and sarcoma 180, Ehrlich and Mep 2 ascites cells in vivo (33-35). RC-RNase isolated from $R$. catesbeiana is identical to $\operatorname{SBL}(36,37)$. It was also reported that RC-RNase seems to harbor a more specific anticancer activity compared with onconase (38).

However, the mechanism of antitumor effect of SBL is unclear and the validity for human leukemia cells has not been fully studied. We studied the antitumor effect of SBL using some human leukemia cell lines. We found that SBL shows cytotoxicity to some cell lines, including multiple drug resistant (MDR) cells. The mechanism of SBL-induced cytotoxicity is analyzed in detail by combinational usage of specific caspase inhibitors and mitochondrial membrane depolarization detector JC-1 and we clearly show that cytotoxicity is induced through caspase-dependent apoptosis in which mitochondrial perturbation occurs as upstream events. It is extrapolated that the novel mechanistic apoptosis inducing activity toward various human leukemia cells regardless of $\mathrm{P}$-glycoprotein ( $\mathrm{P}-\mathrm{gp}$ ) expression indicating that SBL is a new candidate as an alternative to conventional DNA-damaging anticancer drugs.

\section{Materials and methods}

Materials. SBL was isolated in sequential chromatography on Sephadex G-75, DEAE-cellulose, hydroxyapatite and SP-Sepharose as described previously (28). Etoposide (ETO), doxorubicin (DOX) and anti- $\beta$-actin antibody were purchased from Sigma-Aldrich (Tokyo, Japan). Tumor necrosis factor-related apoptosis inducing ligand (TRAIL) was purchased from R\&D Systems (Minneapolis, MN, USA). Caspase inhibitors (zVAD-fmk, zIETD-fmk, zLEHD-fmk) and anti-caspase-9 antibody were purchased from Medical \& Biological Laboratories Co., Ltd. (MBL, Nagoya, Japan). Anti-caspase-8 antibody, anti-caspase-3 antibody and antiBid antibody were purchased from Cell Signaling Technology (Beverly, MA, USA). Anti-cytochrome $c$ antibody was purchased from Becton-Dickinson (Franklin Lakes, NJ, USA). Horseradish peroxidase (HRP)-conjugated anti-mouse IgG actibody and HRP-conjugated anti-rabbit IgG andibody was purchased from Zymed (South San Francisco, CA, USA) and Cedarlane Lab. Ltd. (Hornby, Ontario, Canada), respectively.

Cell culture. Human leukemia Jurkat T-cells, erythroleukemia K562 cells, Adriamycin-resistant and P-gp-overexpressing K562 cells (K562/ADR), Burkitt's lymphoma Raji cells and promyelocytic leukemia U937 cells were obtained from the Cell Resource Center of the Biomedical Research, Institute of Development, Ageing and Cancer, Tohoku University (Sendai, Japan). Cells were routinely kept in RPMI-1640 medium (Nissui Pharmaceutical Co. Ltd., Tokyo, Japan) supplemented with $10 \%$ fetal calf serum (FCS), penicillin (100 U/ml) and streptomycin $(100 \mu \mathrm{g} / \mathrm{ml})$ at $37^{\circ} \mathrm{C}$ in a $95 \%$ air and $5 \% \mathrm{CO}_{2}$ atmosphere.
RNA extraction and analysis. The cells were treated with SBL $(2 \mu \mathrm{M})$ for indicated time. Total RNA of the cells was extracted with TRIzol reagent (Invitrogen, Carlsbad, CA, USA) according to the manufacturer's instructions. RNA $(1 \mu \mathrm{g})$ was electrophoresed on $2 \%$ agarose gel containing formaldehyde $(18 \%)$. The gels were visualized by ethidium bromide staining.

Measurement of cell viability. To determine the cytotoxicity, WST-8 assays (39), were done in accordance with the manufacturer's instructions. Briefly, the cells $\left(2 \times 10^{4}\right.$ cells/well) were plated into 96-well plates. Various concentration of reagents were added in triplicate to the cultures and incubated for indicated times before adding the WST- 8 solution. The absorbance of the resulting product was measured $4 \mathrm{~h}$ later at a wavelength of $450 \mathrm{~nm}$ with back ground subtraction at $650 \mathrm{~nm}$. The $\mathrm{IC}_{50}$ which shows the compound concentration required for $50 \%$ inhibition of the cell growth was calculated employing GraphPad Prism 3.0 software. Cell viability was determined by trypan blue dye exclusion assay. The cells $\left(2 \times 10^{5}\right.$ cells $\left./ \mathrm{ml}\right)$ were cultured in $100 \mu \mathrm{l}$ in 96 -well plates. After treatment with SBL, the cells were stained with $0.25 \%$ trypan blue and both viable and non-viable cells were counted.

Observation of nuclear morphology. The cells $\left(2 \times 10^{5}\right.$ cells/ $\mathrm{ml}$ ) were cultured in $5 \mathrm{ml}$ in 6-well plates. After treatment with SBL, the cells were collected by centrifugation and washed with PBS. Then the cells were fixed with $1 \%$ paraformaldehyde (100 $\mu \mathrm{l}$ ) for $15 \mathrm{~min}$ at $4^{\circ} \mathrm{C}$, and stained with Hoechst 33258 $(50 \mu 1,1 \mathrm{mg} / \mathrm{ml})$ for $15 \mathrm{~min}$ at $4^{\circ} \mathrm{C}$. After three washes with PBS, the cells were mounted on slide glass using Prolong gold antifade reagent (Molecular Probes). The fluorescence was visualized with a fluorescence microscope, Zeiss Axioscope 2 (Carl Zeiss, Jena GmbH, Jena, Germany).

Detection of DNA fragmentation. The cells $\left(2 \times 10^{5}\right.$ cells $\left./ \mathrm{ml}\right)$ were cultured in $100 \mu \mathrm{l}$ in 96 -well plates. After treatment with SBL, the cells were collected by centrifugation, washed with PBS, then lysed with cell lysis buffer $[50 \mathrm{mM}$ Tris- $\mathrm{HCl}$ (pH 6.8), 10 mM EDTA, 0.5\% w/v sodium-N-lauroylsarcosinate]. The samples were incubated for $30 \mathrm{~min}$ with RNase A (final concentration, $500 \mu \mathrm{g} / \mathrm{ml}$ ) at $50^{\circ} \mathrm{C}$, before being digested for $30 \mathrm{~min}$ with proteinase $\mathrm{K}$ (final concentration, $500 \mu \mathrm{g} / \mathrm{ml})$ at $50^{\circ} \mathrm{C}$. Then the samples were electrophoresed on $1.8 \%$ agarose gel, DNA bands were visualized by ethidium bromide staining.

Flow cytometric analysis of Annexin $V$ binding and propidium iodide (PI) incorporation. Annexin V binding and PI incorporation were detected with a MEBCYTO apoptosis kit (MBL) according to the manufacturer's instructions. The cells $\left(2 \times 10^{5}\right.$ cells $\left./ \mathrm{ml}\right)$ were cultured in $1 \mathrm{ml}$ in 24 -well plates. Fluorescence intensity of fluorescein isothiocyanate (FITC)Annexin V and PI was determined using a FACSCalibur flow cytometer (Becton-Dickinson).

Detection of caspase activity. Caspase activity was measured with caspase colorimetric protease assay kit (MBL) in accordance with the manufacturer's instructions. After treatment with SBL $(2 \mu \mathrm{M})$ for indicated time, cells were lysed with cell lysis buffer and incubated for $10 \mathrm{~min}$ at $4^{\circ} \mathrm{C}$. Then samples 
Table I. Inhibitory effect of SBL, ETO and DOX on the viability of human leukemia cell lines.

\begin{tabular}{llccc}
\hline & & \multicolumn{3}{c}{$\mathrm{IC}_{50}(\mathrm{mM})$} \\
\cline { 3 - 5 } Cell name & \multicolumn{1}{c}{ Characteristics } & SBL & ETO & DOX \\
\hline Jurkat & T-cell leukemia & $0.15 \pm 0.07$ & $2.09 \pm 0.78$ & $1.10 \pm 0.71$ \\
K562 & Erythroleukemia & $1.39 \pm 0.92$ & $13.23 \pm 3.86$ & $3.51 \pm 1.84$ \\
K562/ADM & P-glycoprotein-overexpressing K562 cells & $0.36 \pm 0.18$ & N/A & N/A \\
U937 & Promyelocytic leukemia & $0.81 \pm 0.24$ & $0.46 \pm 0.09$ & $0.34 \pm 0.27$ \\
Raji & Burkitt's lymphoma & $0.88 \pm 0.54$ & $0.49 \pm 0.04$ & $0.28 \pm 0.19$ \\
\hline
\end{tabular}

Cells were treated with SBL, ETO or DOX for $72 \mathrm{~h} . \mathrm{IC}_{50}$ is the concentration which resulted in a $50 \%$ decrease in cell viability. Each value indicates the mean $\pm \mathrm{SD}$ of three different experiments performed in triplicate.

were centrifuged at $12,400 \mathrm{rpm}$ and supernatant was collected. Samples $(50 \mu \mathrm{l}, 1 \mu \mathrm{g} / \mu \mathrm{l})$ were mixed with equal amount of $2 \mathrm{X}$ reaction buffer and substrates (DEVD-pNA for caspase-3, LEHD-pNA for caspase-9, IETD-pNA for caspase-8) were added at final concentration $200 \mu \mathrm{M}$. After incubation for $2 \mathrm{~h}$ at $37^{\circ} \mathrm{C}$, the absorbance of the resulting product was measured at a wavelength of $405 \mathrm{~nm}$.

Treatment of caspase inhibitors. The role of caspase activation in the process was studied by the addition of zVAD-fmk (pancaspase inhibitor), zIETD-fmk (caspase- 8 specific inhibitor) and zLEHD-fmk (caspase-9 specific inhibitor). Each caspase inhibitor $(50 \mu \mathrm{M})$ was added to culture medium $30 \mathrm{~min}$ before the addition of reagents.

Western blotting. Whole cell lysate was prepared by lysing the cells with extraction buffer $[150 \mathrm{mM} \mathrm{NaCl}, 1 \%$ Triton X-100, $10 \mathrm{mM}$ Tris-HCl (pH 7.5), 5 mM EDTA (pH 8.0), $1 \mathrm{mM}$ phenylmethylsulfonyl fluoride (PMSF), 1 tablet/10 $\mathrm{ml}$ protease inhibitor cocktail (Roche Applied Science, Indianapolis, IN, USA)]. Lysates of organelle (mitochondria) fraction or cytosol fraction were prepared by ProteoExtract Subcellular Proteome Extraction Kit (Merck Millipore, Billerica, MA, USA). Soluble proteins were collected and concentrations were measured by DC protein assay kit (Bio-Rad, Richmond, CA, USA) in accordance with instructions. Proteins were separated by SDS-PAGE and transferred to polyvinylidene difluoride (PVDF) membrane (GE Healthcare, Little Chalfont, UK). The membrane was blocked by $5 \%$ fat-free skim milk for $1 \mathrm{~h}$. After the membrane was washed with TBST [20 mM Tris- $\mathrm{HCl}$ (pH 7.6), $137 \mathrm{mM} \mathrm{NaCl}, 0.05 \%$ Tween-20], primary and secondary antibodies were added to the membrane, respectively. The proteins on membrane were detected using ECL western blotting detection regents (GE Healthcare).

Detection of mitochondrial membrane potential (MMP) reduction. MMP was assessed using a fluorescent probe 5,50,6,60-tetrachloro-1,10,3,30-tetraethyl-benzamidazolocarbocyanin iodide (JC-1, AnaSpec, Fremont, CA, USA). Red emission from the dye is attributed to a potential-dependent aggregation of JC-1 in the mitochondria. Green fluorescence reflects the monomeric form of JC-1, appearing in the cyto- plasm after mitochondrial membrane depolarization. Cells were cultured in condition of each experiment and then incubated with $\mathrm{JC}-1(2 \mu \mathrm{M})$ dye diluted in culture medium at $37^{\circ} \mathrm{C}$ for $15 \mathrm{~min}$. The cells were washed three times with PBS and analyzed immediately using FACSCalibur (BectonDickinson).

Statistical analysis. Results were collected from three independent experiments, each performed in triplicate and data are expressed as mean \pm SD. Statistical analysis was performed using GraphPad Prism 3.0 and comparisons were made using one-way or two-way analysis of variance (ANOVA), followed by Bonferroni's post hoc tests.

\section{Results}

SBL shows cytotoxicity to some human leukemia cell lines including MDR cells. We have previously shown that SBL has antitumor activity against mouse leukemia cells in vitro and in vivo $(33,34,40)$. In this study, antitumor activity of SBL for human leukemia cell line and the signaling mechanism was evaluated. To determine the effect of SBL on cell viability of some human leukemia cell lines, WST assay was performed. As shown in Table I, SBL shows cytotoxic effect for all cell lines tested at low concentration $(0.15-1.39 \mu \mathrm{M})$ and the lowest $\mathrm{IC}_{50}$ value was observed in Jurkat cells $(0.15 \mu \mathrm{M})$. The cytotoxic effect of SBL was observed regardless of the P-gp expression level, while ETO and DOX which are used clinically for leukemia as DNA damaging agent did not cause cytotoxic effect on P-gp-overexpressing K562 cells.

SBL degrades cellular RNA and inhibits cell proliferation of Jurkat cells. Because SBL has pyrimidine base-specific ribonuclease activity $(31,32)$, we analyzed whether the cellular RNA is degraded by SBL or not. Total RNA extracted from SBL-treated Jurkat cells was analyzed by agarose gel electrophoresis and partial RNA degradation was found from 3-h treatment, then increased time-dependently (Fig. 1A). Next, the effects of SBL on Jurkat cell proliferation were analyzed in detail. Trypan blue dye exclusion assay showed that SBL $(2 \mu \mathrm{M})$ exhibited cytotoxicity toward Jurkat cells from $24 \mathrm{~h}$ time-dependently and that SBL $(0.2 \mu \mathrm{M}$ or above) exhibited 
A

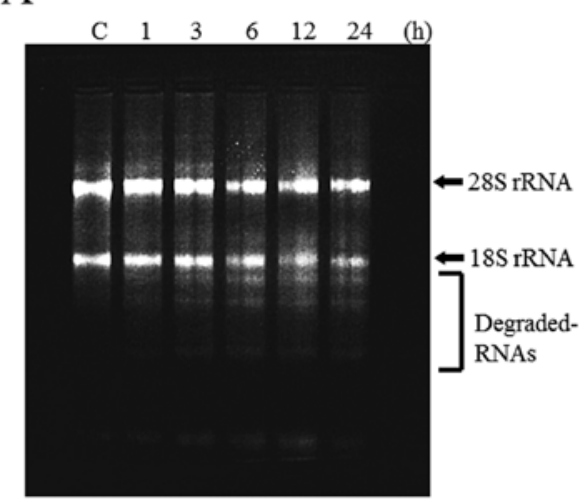

$\mathrm{C}$

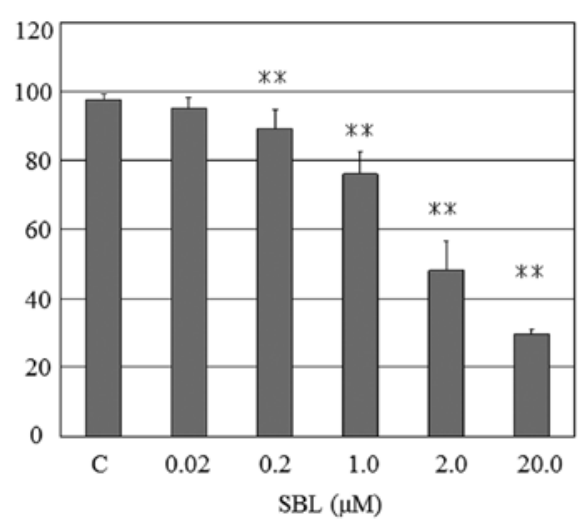

B

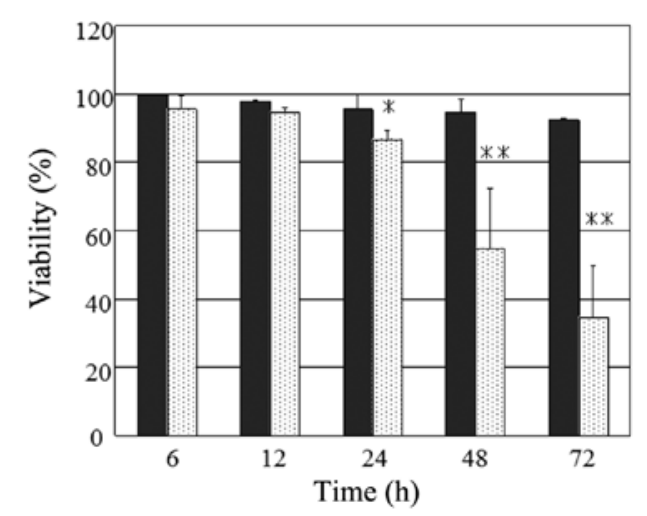

$\mathrm{D}$

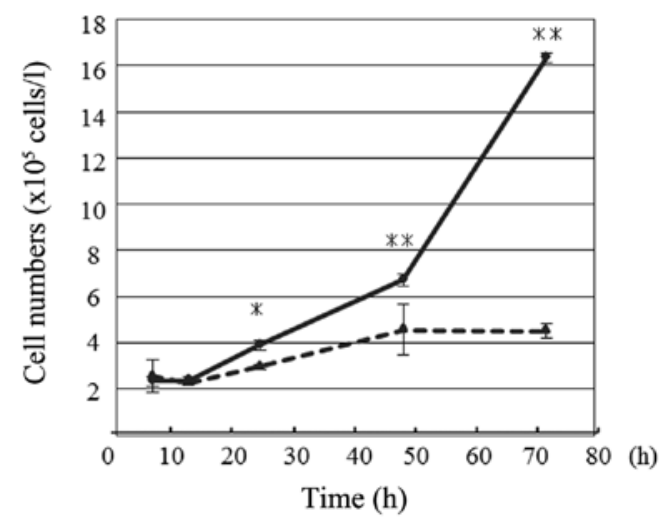

Figure 1. SBL degrades cellular RNA and inhibits cell proliferation of Jurkat cells. (A) Cells were treated with SBL ( $2 \mu \mathrm{M})$ for indicated time and RNA was extracted. Then, electrophoresis was performed on 1.5\% agarose gel. C, control. Degraded RNAs were seen under 18S rRNA. (B) Cells were treated with (doted column) or without (filled column) SBL $(2 \mu \mathrm{M})$ for indicated time. Cell viability was evaluated by trypan blue dye exclusion assay. (C) Cells were treated with SBL at various concentrations for $48 \mathrm{~h}$. Cell viability was evaluated by the method described above. C, control. (D) Cells were treated with (dotted line) or without (solid line) SBL $(2 \mu \mathrm{M})$ for indicated time and total cell number were counted. Each value represents the mean \pm SD of three independent experiments. " $\mathrm{p}<0.05$ and $^{* *} \mathrm{p}<0.01$ vs. control.

cytotoxicity in 48-h treatment concentration-dependently (Fig. 1B and C). Furthermore, significant inhibition of Jurkat cell proliferation was observed from 24-h treatment (Fig. 1D).

SBL induces apoptosis in Jurkat cells. To study the mechanism involved in the cytotoxicity of SBL, first we investigated the morphological changes in SBL-treated Jurkat cells using Hoechst 33258. Exposure of SBL resulted in typical apoptotic morphological alterations, such as karyorrhexis, nuclear condensation and nuclear fragmentation (Fig. 2A). We further observed the apoptotic biological changes in SBL-treated Jurkat cells. Annexin-V binding which is attributed to externalization of phosphatidylserine (PS) was observed from 3-h treatment of SBL (Fig. 2B). Simultaneously, the activation of initiator caspase (-8 and -9$)$ and effector caspase (-3) was observed from 3 or $6 \mathrm{~h}$ (Fig. 2C). Similarly, DNA fragmentation was observed in a dose-dependent manner (Fig. 2D). These data indicate that SBL induces apoptosis in Jurkat cells.

SBL-induced apoptosis is dependent on caspases and caspase- 9 is activated more strongly than caspase-8. To analyze the detail of SBL-induced caspase activation, we performed experiments using caspase inhibitors. Pretreatment of z-VAD inhibited SBL-induced cell death (Fig. 3A) and completely blocked SBL-induced DNA fragmentation (Fig. 3B). Next, we analyzed activation pattern of caspase-8, -9 and -3 under the presence of specific inhibitors for each of the caspases (Fig. 4). Pretreatment of caspase-9 inhibitor, z-LEHD, inhibited activation of caspase-8. On the other hand, pretreatment of caspase- 8 inhibitor, z-IETD, could not inhibit caspase- 9 activation and the activation of caspase- 9 was not affected even by the treatment of z-VAD or z-LEHD. Pretreatment of caspase-3 inhibitor, z-DEVD did not have an effect on activation of caspase- 8 or -9 . These data indicate that SBL induces caspase-dependent apoptosis and caspase- 9 is activated strongly in SBL-induced apoptosis.

SBL induces activation of $p 38$ and JNK, but not ERK. We monitored the activation of mitogen-activated protein kinases (MAPKs), extracellular signal-regulated kinases (ERKs), c-jun $\mathrm{N}$-terminal kinase $(\mathrm{JNKs}) /$ stress-activated protein kinases and p38 in SBL-treated cells. Fig. 5 shows p38 kinase was activated as early as $1 \mathrm{~h}$ and sustained to $12 \mathrm{~h}$. Furthermore, activation of JNK1/2 was observed from 1-h treatment and maximal at 
A
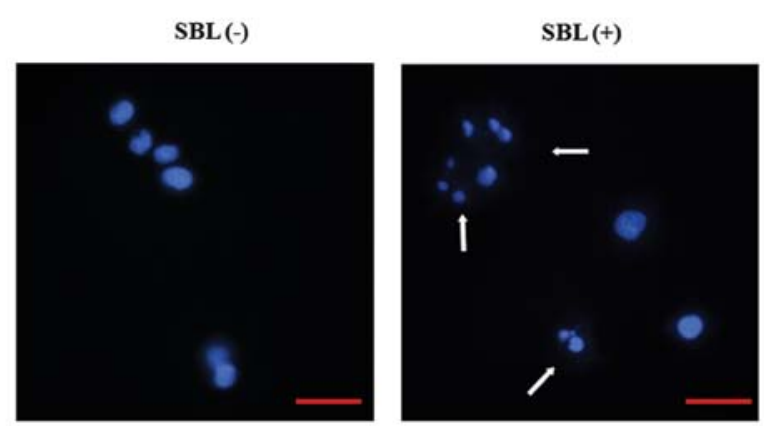

B
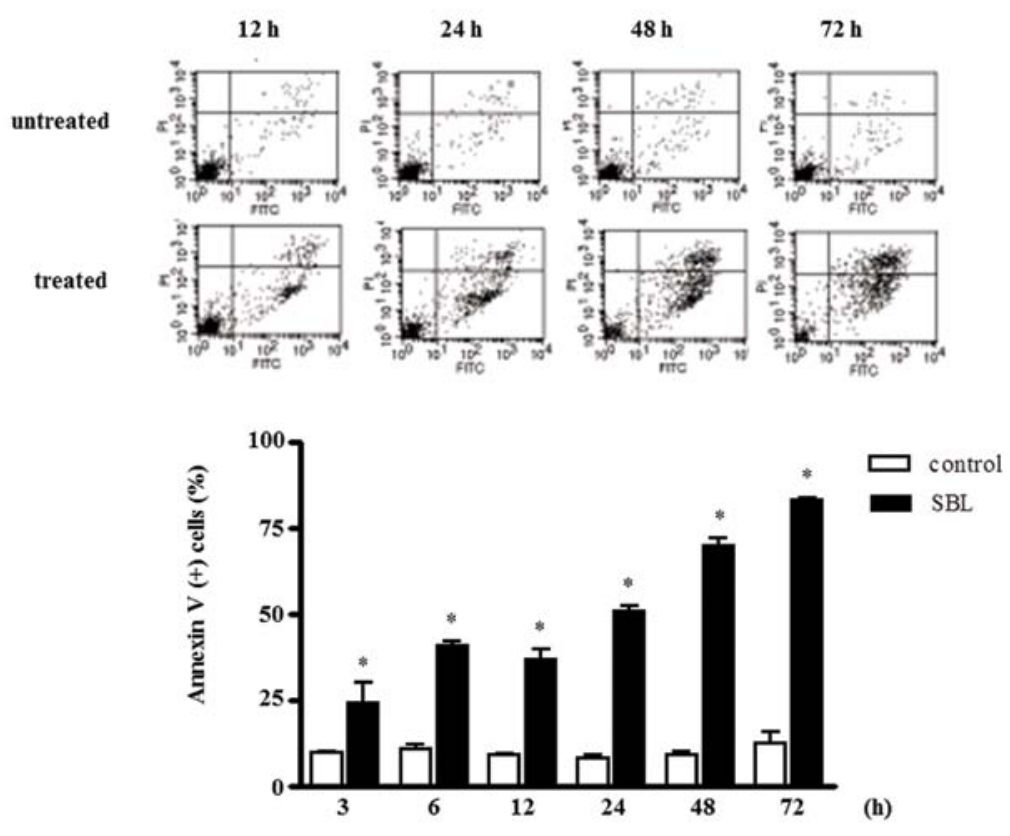

$\mathrm{C}$

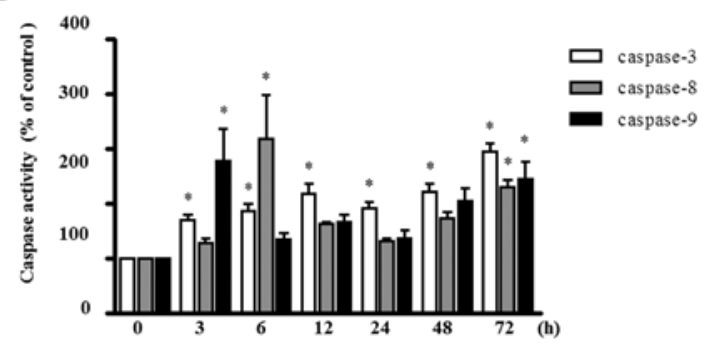

D

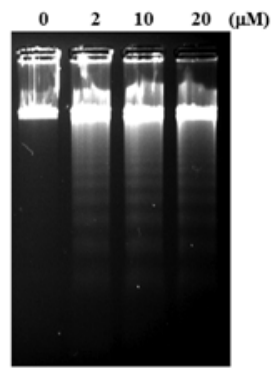

Figure 2. SBL induces apoptosis in Jurkat cells. (A) Morphological changes of nuclei in SBL-treated Jurkat cells. Cells were treated with SBL ( $2 \mu \mathrm{M})$ for $48 \mathrm{~h}$ and stained with Hoechst 33258. Nuclei were observed using a fluorescent microscope. SBL-untreated (left panel) and -treated (right panel) cells. Arrows indicate apoptotic nuclei. Magnification, x40 (scale, $10 \mu \mathrm{m}$ ). (B) Time-dependent changes of FITC-Annexin V binding and PI incorporation in SBL-treated Jurkat cells. Cells were treated with SBL $(2 \mu \mathrm{M})$ for indicated time. Then, analysis of Annexin V-bound vs. PI incorporated cells was performed by FACSCalibur. In the lower panel, the percentage of Annexin V-positive cells is presented. Each value is the mean \pm SE of three independent experiments. " $\mathrm{p}<0.05$ vs. untreated cells. (C) Caspase activity of SBL-treated Jurkat cells. Cells were treated with SBL $(2 \mu \mathrm{M})$ for indicated time. Then, the activity of each caspase was measured using fluorometric assay kit. (D) DNA fragmentation in SBL-treated Jurkat cells. Cells were treated with SBL at indicated concentrations for $48 \mathrm{~h}$ and DNA was prepared from the cells. DNA fragmentation was analyzed by agarose gel electrophoresis and stained with ethidium bromide.

6-9 h, whereas, activation of ERK was not observed in this condition. These results suggest that $\mathrm{p} 38$ and JNK may be involved in SBL-induced apoptotic signaling.

Mitochondrial perturbation occurs before activation of caspases. Because caspase-9 is known as initiator caspase in apoptosis through mitochondria pathway, we analyzed the mitochondrial perturbation in SBL-induced apoptosis. During apoptosis, loss of mitochondrial membrane potential (MMP) is observed. We detected mitochondrial membrane depolarization using JC-1 fluorescent dye in SBL-treated Jurkat cells and found that SBL caused mitochondrial membrane depolarization in a time-dependent manner (Fig. 6A). At the same time, release of cytochrome $c$ from mitochondria to cytosol was also observed (Fig. 6B) and the cleavage of Bid, which causes an efflux of cytochrome $c$ from the mitochondria, was observed from 6 h. These results show occurrence of mitochondrial perturbation in SBL-treated Jurkat cells.

To study the importance of mitochondrial perturbation in SBL-induced apoptosis, we analyzed cell viability and the mitochondrial depolarization under the presence of caspase inhibitors comparing with TRAIL and ETO known as inducer of apoptosis through death receptor pathway and mitochondrial pathway, respectively. At 48-h treatment with each of the reagents, pretreatment of z-VAD completely inhibited TRAIL-induced cytotoxicity, but did not or only partially inhibited SBL- or ETO-induced cytotoxicity (Fig. 7A). Similarly, mitochondrial depolarization caused by TRAIL was completely inhibited by z-VAD, while SBL or ETO-induced mitochondrial depolarization was not affected by z-VAD (Fig. 7B). Furthermore, z-IETD inhibited TRAILinduced mitochondrial depolarization to similar extent with 

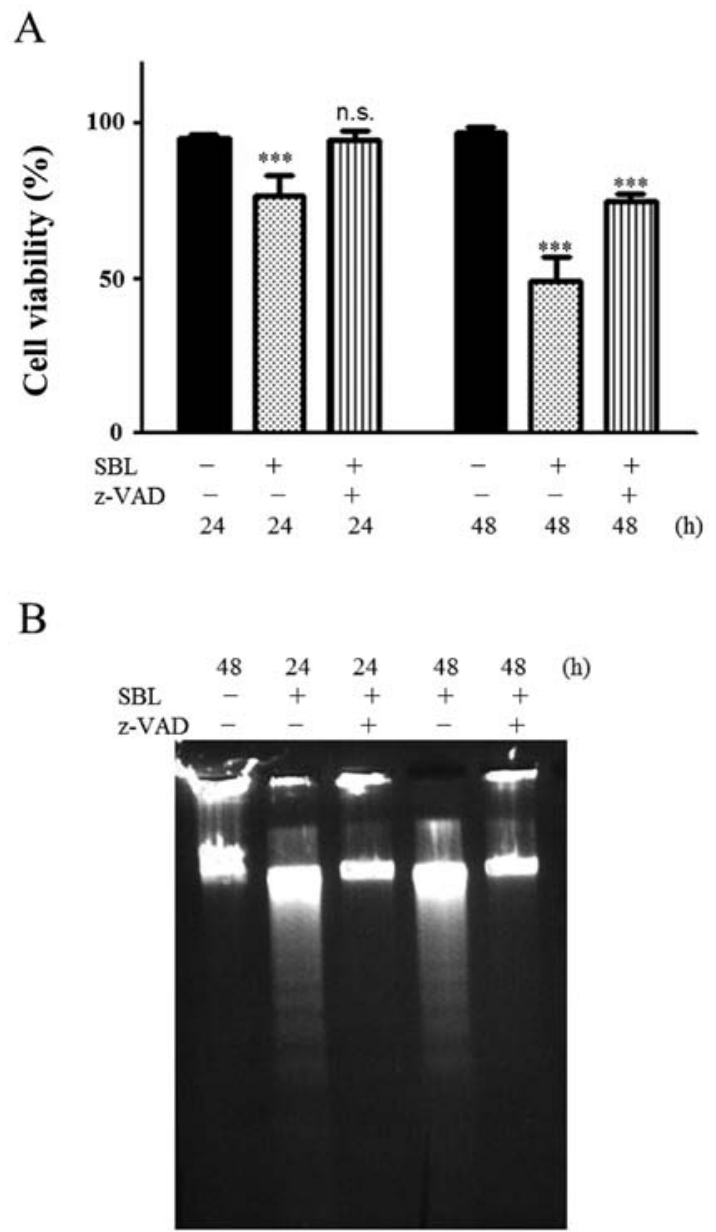

Figure 3. SBL-induced apoptosis is dependent on caspases. (A) Effect of z-VAD on SBL-induced cell death. Cells were treated with (striped column) or without (dotted column) z-VAD-fmk $(50 \mu \mathrm{M})$ for $30 \mathrm{~min}$ and subsequently treated with SBL $(2 \mu \mathrm{M})$ for indicated time. Cell viability was evaluated by trypan blue dye exclusion assay. Control (black column). Bars, mean \pm SD. ${ }^{* * *} \mathrm{p}<0.001$. (B) Effect of $\mathrm{z}-\mathrm{VAD}$ on DNA fragmentation in SBL-treated cells. Cells were treated with or without $z$-VAD-fmk $(50 \mu \mathrm{M})$ for $30 \mathrm{~min}$ and subsequently treated with SBL $(2 \mu \mathrm{M})$ for indicated time. Then, DNA was prepared from the cells. DNA fragmentation was analyzed by agarose gel electrophoresis and stained with ethidium bromide.

z-VAD, whereas, z-LEHD was less effective. On SBL- or ETO-induced mitochondrial depolarization, neither IETD nor LEHD showed inhibitory effect like z-VAD (Fig. 7C). These results indicate that SBL-induced mitochondrial perturbation is not dependent on caspase activation. Thus, SBL invokes mitochondrial perturbation first and this process is followed by caspase activation and the amplification of death signal executes apoptotic cell death.

\section{Discussion}

SBL is a multifunctional protein which has lectin activity, ribonuclease activity and antitumor activity. The proposed mechanism of SBL-induced cell death is shown in Fig. 8. SBL binds to cell surface, internalizes into tumor cells and degrades cellular RNA and this ribotoxic stress triggers mitochondrial perturbation. The activation of $\mathrm{p} 38$ and JNK may be involved in the above process. Then, apoptotic signal is amplified by activation of caspase and leads to cell death.
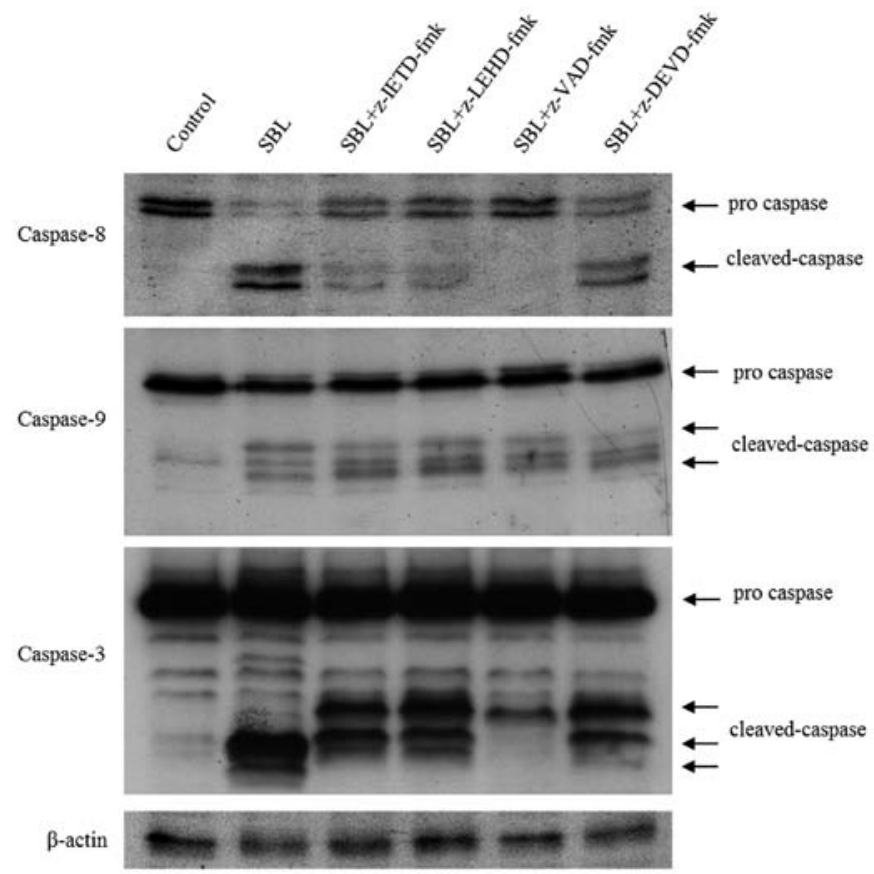

Figure 4. Effect of caspase inhibitors on SBL-induced caspase activation in Jurkat cells. Cells were treated with or without caspase inhibitor $(50 \mu \mathrm{M})$ for $30 \mathrm{~min}$ and subsequently treated with SBL $(2 \mu \mathrm{M})$ for $12 \mathrm{~h}$. Then, whole cell lysate was separated by SDS-PAGE in $15 \%$ gel and subjected to western blot analysis using specific antibodies. $\beta$-actin was probed to demonstrate equal loading.

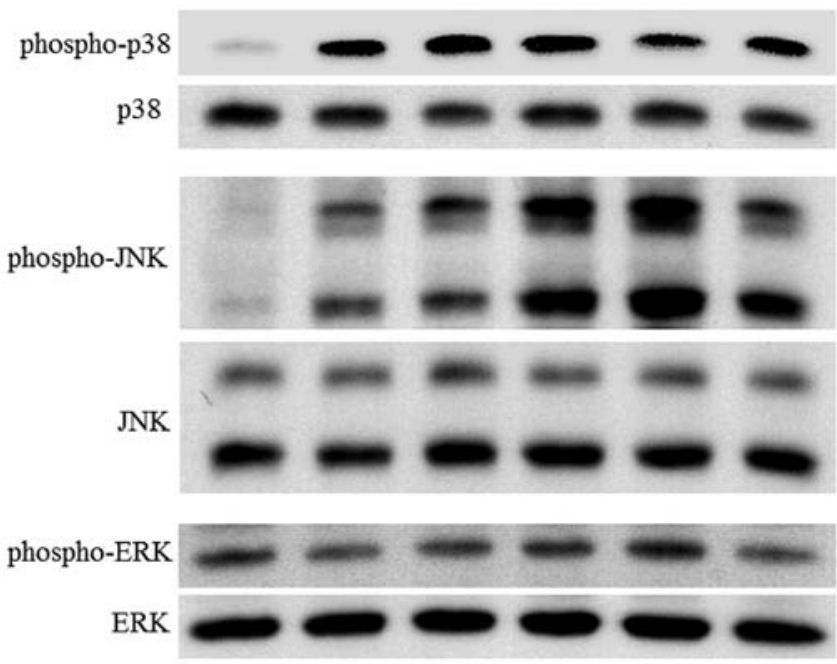

Figure 5. SBL induces activation of $\mathrm{p} 38$ and JNK but not activation of ERK. Cells were treated with SBL $(2 \mu \mathrm{M})$ for indicated time and phosphorylation status of $\mathrm{p} 38$, JNK and ERK were determined by western blot analysis. Expression of total p38, JNK and ERK was also determined to confirm equal amount of protein loading in each lane.

SBL selectively agglutinates tumor cells, but not erythrocytes or fibroblasts (28). SBL shows cytotoxity to various tumor cells, but not to human primary WI-38 lung fibroblasts, normal mesothelial Met-5A cells (data not shown), human primary HFW fibroblasts, immortalized murine NIH- 3T3/3 cells (40), human primary HS-68 foreskin fibroblasts (37) or 


\section{A}
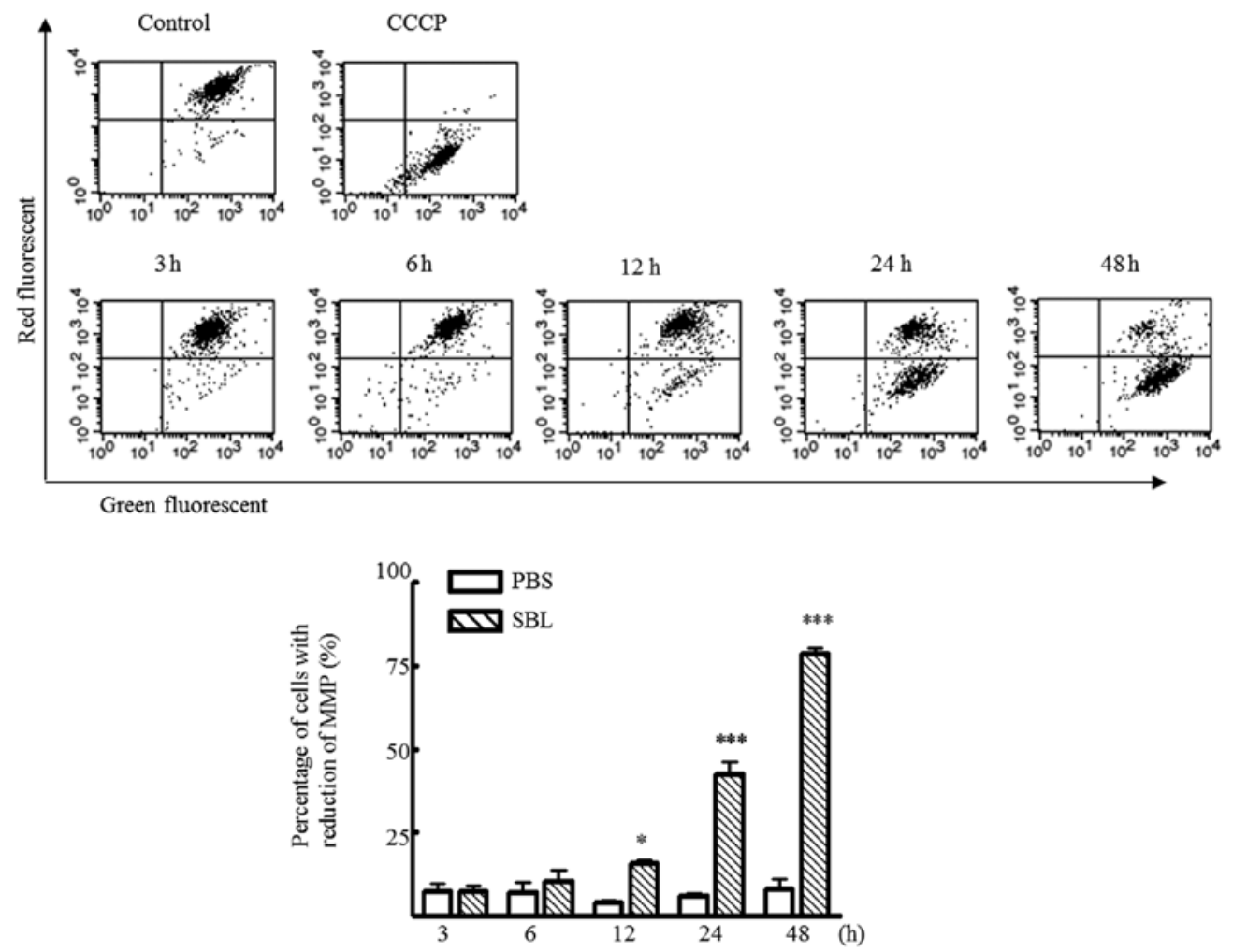

B

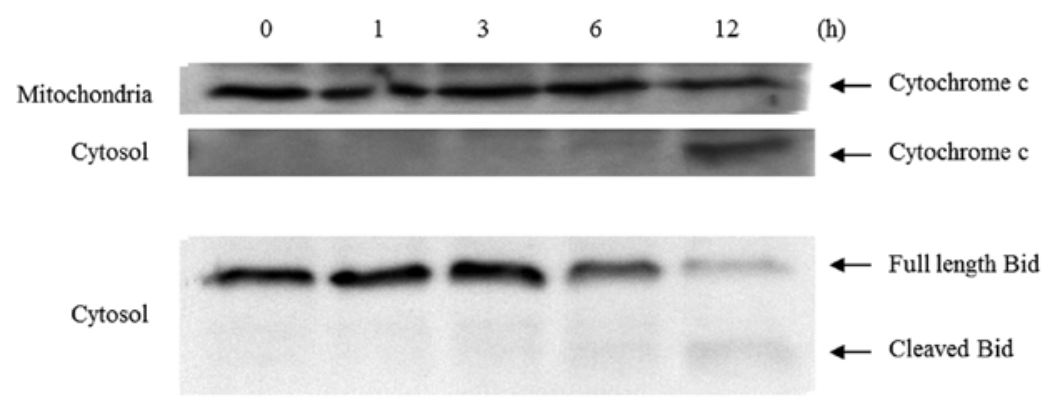

Figure 6. SBL induces mitochondrial perturbation in Jurkat cells. (A) Effect of SBL on MMP. Cells were treated with or without SBL ( $2 \mu$ M) for indicated time. Then, the cells were stained with JC-1 (mitochondria selective dye) and analyzed using FACSCalibur. In lower panel, the percentage of cells with reduced MMP (lower right quadrant of each dot plot) was represented. Each value represents the mean \pm SD of three independent experiments. (B) Release of cytochrome $c$ from mitochondria to cytosol and Bid cleavage in SBL-treated cells. Cells were treated with SBL ( $2 \mu \mathrm{M})$ for indicated time. Then, organelle and cytosol fractions were separated by SDS-PAGE in 15\% gel and subjected to western blot analysis using anti-cytochrome $c$ antibody and anti-Bid antibody.

hamster kidney BHK-21 cells (41). It seems that the selective effect of SBL on cancer cells is due to its selective binding to tumor cells, because sialidase treatment of cells abolished the tumor cell agglutination and also the antiproliferative effect induced by SBL (33).

In this study, we showed that SBL manifests cytotoxicity to some human leukemia cell lines including MDR cells, while conventional DNA-damaging agents, ETO and DOX which have been used clinically were not able to show cytotoxicity to MDR cells (Table I). The resistance of tumors occurs as a cross-resistance to a whole range of drugs with different structures and this phenomenon is called MDR. The cytotoxic drugs that are most frequently associated with MDR are hydrophobic and amphipathic natural products, such as the taxanes (paclitaxel and docetaxel), vinca alkaloids (vinorelbine, vincristine and vinblastine), anthracyclines (DOX, daunorubicin and epirubicin), epipodophyllotoxins (ETO and teniposide), antimetabolites (methorexate, fluorouracil, cytosar, 5-azacytosine, 6-mercaptopurine and gemcitabine), topotecan, dactinomycin and mitomycin $c$ (42-46). Overexpression of ATP-binding cassette (ABC) transporters such as P-gp is known to be responsible for MDR (46). Cytotoxic RNase, PE5 (a variant of human pancreatic ribonuclease carrying a nuclear localization signal) reduced the expression level of the P-gp in MDR cell lines (47). It is believed that SBL displays novel mechanistic and tumor-selective cytotoxic effects regardless of P-gp expression and SBL is favorable as a new candidate anticancer drug. 


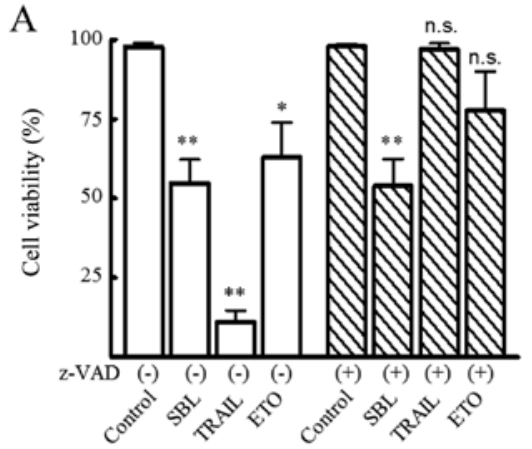

Figure 7. Mitochondrial perturbation occurs in advance of caspase activation. (A) Effect of z-VAD on viability of SBL-, TRAIL- or ETO-treated cells. Cell viability was evaluated by trypan blue dye exclusion assay. Cells were treated with or without z-VAD-fmk $(50 \mu \mathrm{M})$ for 30 min and subsequently treated with SBL $(2 \mu \mathrm{M})$, TRAIL $(5 \mathrm{ng} / \mathrm{ml})$ and ETO $(200 \mu \mathrm{M})$ for $48 \mathrm{~h}$. (B) Effect of z-VAD-fmk on SBL-, TRAIL-, or ETO-induced loss of MMP. MMP were measured as described in Fig. 6. In the lower panel, the percentage of cells with reduced MMP is presented. Each value represents the mean \pm SD of three independent experiments. (C) Effect of z-IETD or z-LEHD on loss of SBL-induced mitochondrial membrane potential. Cells were treated with or without each caspase inhibitor $(50 \mu \mathrm{M})$ for $30 \mathrm{~min}$ and subsequently treated with SBL $(2 \mu \mathrm{M})$, TRAIL $(5 \mathrm{ng} / \mathrm{ml})$ and ETO $(200 \mu \mathrm{M})$, for $48 \mathrm{~h}$. Then, MMP was measured as described above.

\section{B}
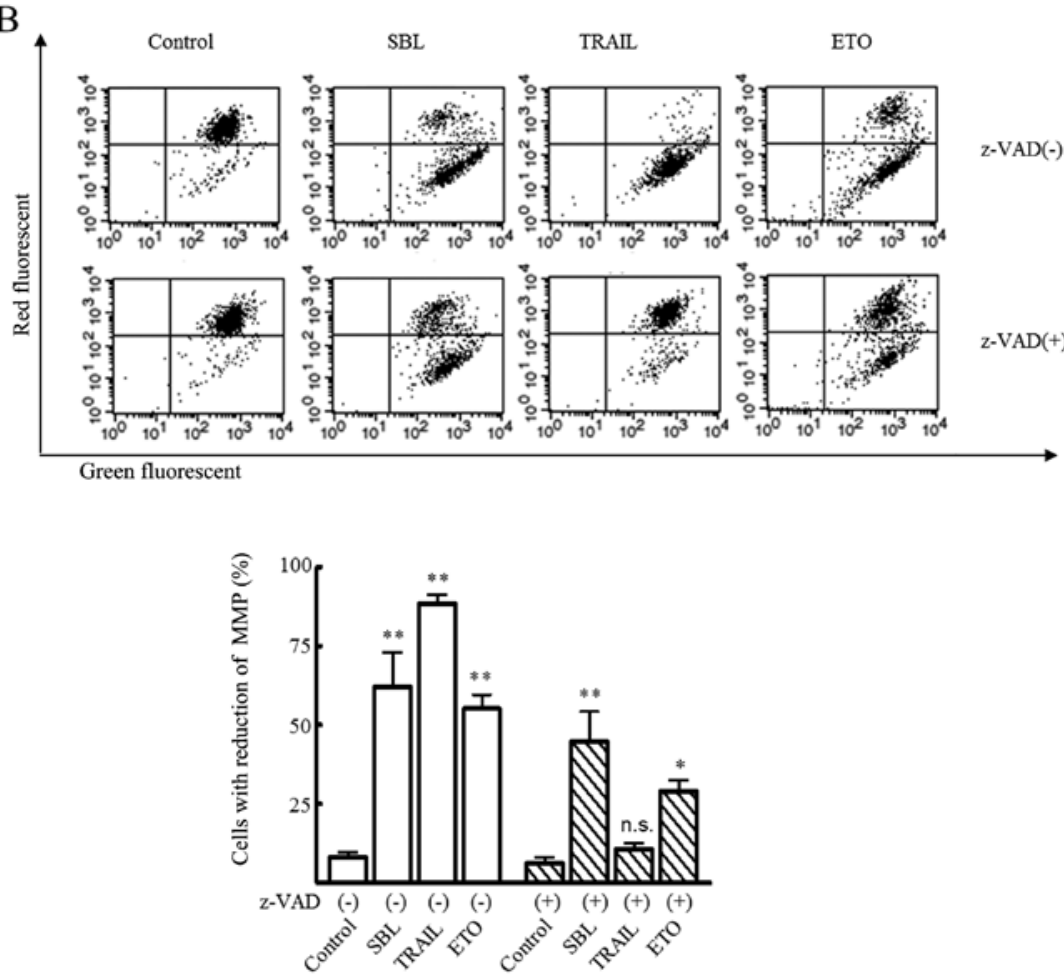

C

Control
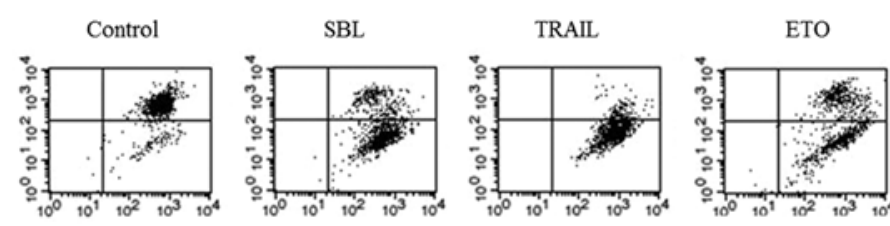

Inhibitor(-)
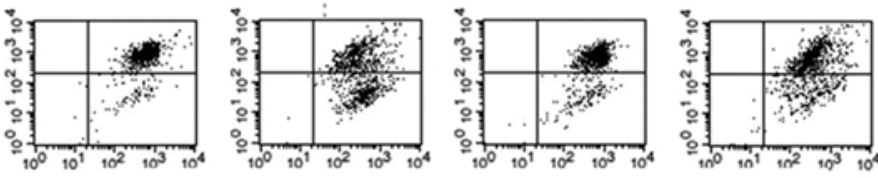

z-VAD

¿ू.
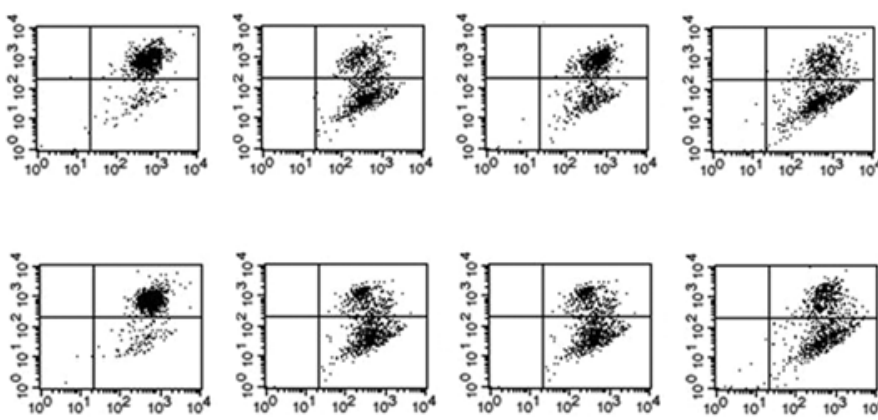

z-IETD
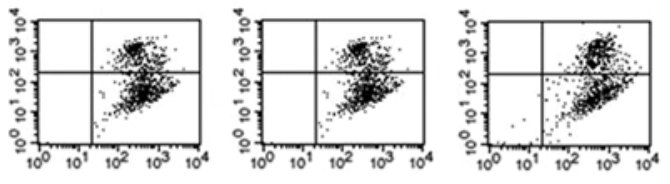

z-LEHD 


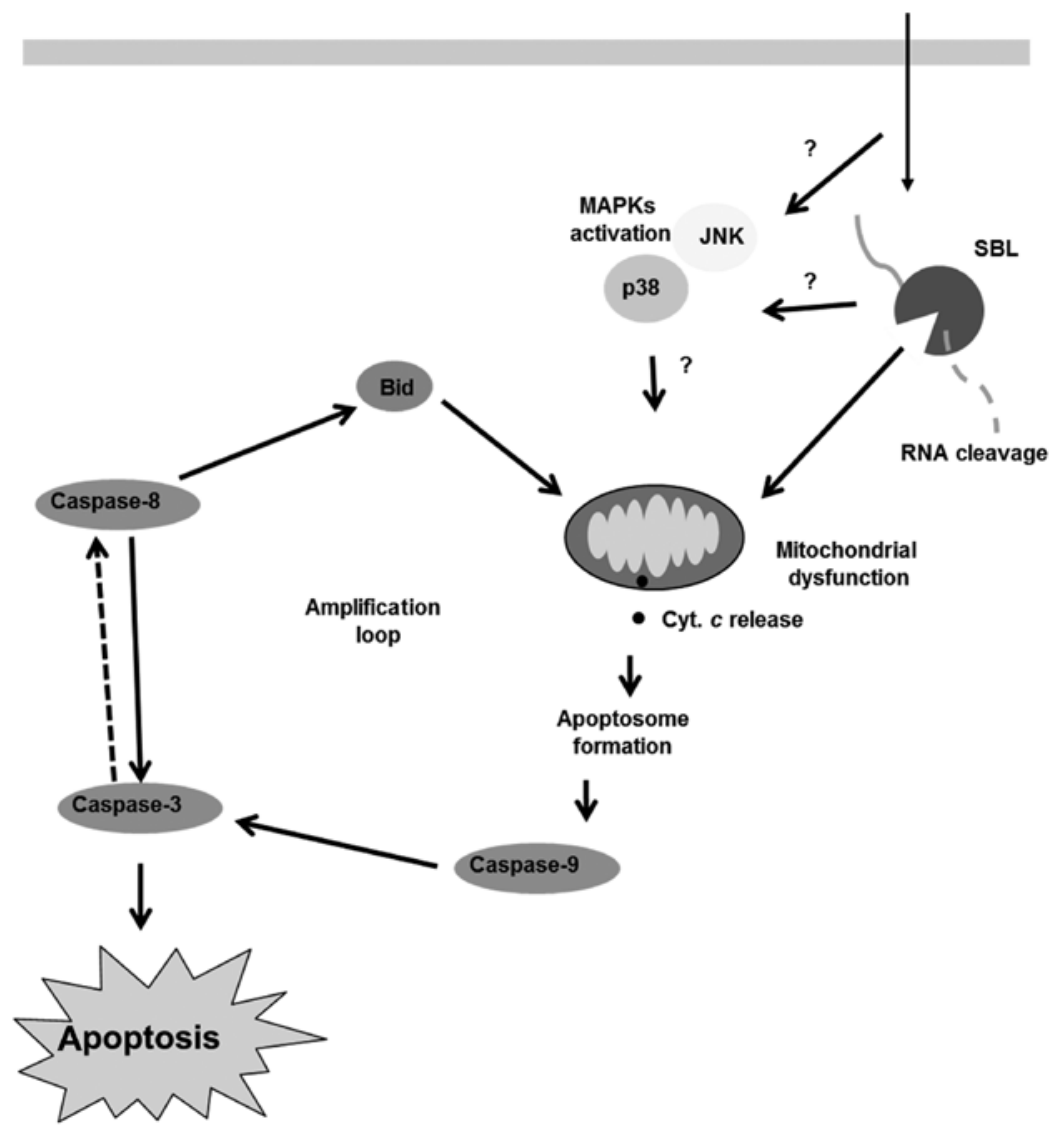

Figure 8. Proposed model for apoptotic mechanism induced by SBL in Jurkat cells. SBL binds to cell surface and internalizes into tumor cells. SBL degrades cellular RNA and this ribotoxic stress triggers mitochondrial perturbation. Then, apoptotic signal is amplified by caspase activation leading to cell death.

Apoptosis, also known as programmed cell death, plays a critical role in various biological phenomena, such as development, immunity and also cell death induced by chemotherapeutic drugs (48). Apoptosis may occur through death receptor-dependent (extrinsic) or independent (intrinsic or mitochondrial) pathways and the pathways finally activate the effector caspase-3, which leads to finally execution of apoptosis (49). During the execution phase of apoptosis, typical apoptotic changes such as chromatin condensation, nuclear collapse, internucleosomal DNA fragmentation are observed. A variety of studies have demonstrated that in cancer therapy, induction of apoptosis is a frequent outcome of effective therapy. In this study, we showed SBL-treated Jurkat cells present typical apoptotic morphological alterations, such as karyorrhexis, nuclear condensation and fragmentation (Fig. 2A) and apoptotic biological changes such as PS externalization, activation of caspases, and DNA fragmentation (Fig. 2B-D). This SBL-induced DNA fragmentation was completely blocked by $\mathrm{z}$-VAD indicating that the cytotoxicity of SBL is induced through caspase-dependent apoptosis.

It has been reported that some chemotherapeutics and natural toxins which induce ribotoxic stress response activates MAPK $(50,51)$. Regarding ribotoxic stress, He et al demonstrated ribotoxins, such as deoxynivalenol (DON), anisomycin, satratoxin $\mathrm{G}(\mathrm{SG})$ and ricin activate $\mathrm{p} 38, \mathrm{JNKs}$ and ERK in RAW264 mouse macrophage cell line (52). It was reported that activation of JNK is important for cytotoxicity of onconase using $j n k 1^{-/} j n k 2^{-/-}$mouse embryo fibroblast
(MEF) cells (53). Fang et al reported that RNase MC2 induces phosphorylation of p38, JNK and ERK in MCF-7 cells (3) and this RNase-mediated apoptotic signaling is contributed by dual phosphorylation of ERK and JNK in Hep G2 cells (54). Although it has been implicated largely that activation of p38 and JNK are proapoptotic $(50,55)$ and that phosphorylation of ERK is linked with both antitumor activity (56) and tumor progression (57), some complicated results have been reported. Costro et al reported that PE5 kills adriamycin-resitant MCF-7 (MCF-7/ADR) cells through apoptosis associated with the inactivation of JNK, while onconase did not change the phosphorylation level of JNK in the cells (25). We showed that SBL is capable of inducing activation of p38 and JNK, but not ERK. The activation of p38 and JNK were observed as early as 1-h treatment with SBL suggesting that p38 and JNK may be activated upstream of mitochondrial perturbation. Although we tested the effects of p38 inhibitor (SP600125) and JNK inhibitor (SB203580), they did not affect the cytotoxicity induced by SBL (data not shown). There are some possible explanations for this phenomenon: i.e., binding to cell surface or the internalization into cytosol is able to display RNase activity of SBL, or the first cleavage of RNA, which is a non-detectable amount by electrophoresis can activate p38 and JNK. In addition, the activation of p38 and JNK may not be related to SBL cytotoxicity, or the inhibition of their activation may induce alternative death signals. The contribution of p38- and JNK-activation in SBL-induced cytotoxicity remains to be elucidated. 
Wolf and Green reported that caspase-3 is capable of eliciting cleavage and activation of caspase-8 (58). Activation of caspase- 8 results in the cleavage of Bid to produce a truncated form of the protein. Truncated Bid translocates from the cytoplasm to the mitochondria, where it appears to interact with and antagonize the actions of anti-apoptotic members of the Bcl-2 family, thereby causing an efflux of cytochrome $c$ from the mitochondria (59-63). This, in turn, can result in the activation of caspase-9. Therefore, caspase- 8 could amplify apoptotic signals through the continued release of cytochrome $c$ and subsequent activation of caspase- 9 and -3 (64). Once activating signals of apoptotic caspase are induced, the amplification signal can activate caspase-8, -9 and -3 . In addition, the determination of exact time course of the sequential events is limited by detection sensitivity of experiments. These facts disturb discrimination of which pathway is involved in the stimuli. We utilized a combination of specific caspase inhibitors and mitochondrial membrane depolarization detector JC-1 to distinguish the SBL-induced signaling pathway comparatively with TRAIL and ETO. It was clearly shown that SBL-induced mitochondrial depolarization was not diminished by z-VAD, while TRAIL-induced mitochondrial depolarization was completely inhibited by z-VAD (Fig. 7A and B). These results indicate that cytotoxicity of SBL is induced through caspase-dependent apoptosis in which mitochondrial perturbation occurs as upstream events.

In conclusion, we report that SBL, a multifunctional protein shows cytotoxicity for some human leukemia cell lines including MDR cells (Fig. 8). The details of apoptotic signal induced by SBL was analyzed by combinational usage of specific caspase inhibitors and the mitochondrial membrane depolarization detector JC-1. The use of this combination was shown in detail to distinguish the apoptotic pathway. SBL displays novel mechanistic and tumor-selective cytotoxic effects regardless of P-gp expression and SBL has potential as an alternative molecule to conventional DNA-damaging anticancer drugs.

\section{Acknowledgements}

This study was supported by the 'Academic Frontier' Project for Private Universities from the Ministry of Education, Culture, Sports, Science and Technology of Japan.

\section{References}

1. Costanzi J, Sidransky D, Navon A and Goldsweig H: Ribonucleases as a novel pro-apoptotic anticancer strategy: review of the preclinical and clinical data for ranpirnase. Cancer Invest 23: 643-650, 2005.

2. Deshpande RA and Shankar V: Ribonucleases from T2 family. Crit Rev Microbiol 28: 79-122, 2002.

3. Fang EF, Zhang CZ, Fong WP and Ng TB: RNase MC2: a new Momordica charantia ribonuclease that induces apoptosis in breast cancer cells associated with activation of MAPKs and induction of caspase pathways. Apoptosis 17: 377-387, 2012.

4. D'Alessio G: New and cryptic biological messages from RNases. Trends Cell Biol 3: 106-109, 1993.

5. Raines RT: Ribonuclease A. Chem Rev 98: 1045-1066, 1998

6. Ita M, Halicka HD, Tanaka T, Kurose A, Ardelt B, Shogen K and Darzynkiewicz Z: Remarkable enhancement of cytotoxicity of onconase and cepharanthine when used in combination on various tumor cell lines. Cancer Biol Ther 7: 1104-1108, 2008 .
7. Rybak SM, Pearson JW, Fogler WE, Volker K, Spence SE, Newton DL, Mikulski SM, Ardelt W, Riggs CW, Kung HF and Longo DL: Enhancement of vincristine cytotoxicity in drugresistant cells by simultaneous treatment with onconase, an antitumor ribonuclease. J Natl Cancer Inst 88: 747-753, 1996.

8. Kim DH, Kim EJ, Kalota A, Gewirtz AM, Glickson J, Shogen K and Lee I: Possible mechanisms of improved radiation response by cytotoxic RNase, Onconase, on A549 human lung cancer xenografts of nude mice. Adv Exp Med Biol 599: 53-59, 2007.

9. Halicka HD, Murakami T, Papageorgio CN, Mittelman A, Mikulski SM, Shogen K and Darzynkiewicz Z: Induction of differentiation of leukaemic (HL-60) or prostate cancer (LNCaP, JCA-1) cells potentiates apoptosis triggered by onconase. Cell Prolif 33: 407-417, 2000.

10. Tsai SY, Hsieh TC, Ardelt B, Darzynkiewicz Z and Wu JM: Combined effects of onconase and IFN-beta on proliferation, macromolecular syntheses and expression of STAT-1 in JCA-1 cancer cells. Int J Oncol 20: 891-896, 2002.

11. Mikulski SM, Viera A, Darzynkiewicz Z and Shogen K: Synergism between a novel amphibian oocyte ribonuclease And lovastatin in inducing cytostatic and cytotoxic effects in human lung and pancreatic carcinoma cell lines. Br J Cancer 66: 304-310, 1992

12. Rutkoski TJ, Kink JA, Strong LE, Schilling CI and Raines RT: Antitumor activity of ribonuclease multimers created by sitespecific covalent tethering. Bioconjug Chem 21: 1691-1702, 2010.

13. Haigis MC, Kurten EL and Raines RT: Ribonuclease inhibitor as an intracellular sentry. Nucleic Acids Res 31: 1024-1032, 2003.

14. Ledoux L and Brachet J: Remarks on preparations of ribonuclease from different manufacturing sources. Biochim Biophys Acta 16: 290,1955

15. Ledoux L: Action of ribonuclease on neoplastic growth. II Action on Landschutz ascites cells in vitro. Biochim Biophys Acta 20: 369-377, 1956.

16. Darzynkiewicz Z, Carter SP, Mikulski SM, Ardelt WJ and Shogen K: Cytostatic and cytotoxic effects of Pannon (P-30 Protein), a novel anticancer agent. Cell Tissue Kinet 21: 169-182, 1988.

17. Easty DM,Ledoux L and Ambrose EJ: The action of ribonuclease on neoplastic growth. III. Studies by interference microscopy. Biochim Biophys Acta 20: 528-537, 1956.

18. Telford IR, Kemp JF, Taylor EF and Yeaman MW: Effect of ribonuclease on survival of ascites tumor bearing mice. Proc Soc Exp Biol Med 100: 829-831, 1959.

19. Ledoux L: Action of ribonuclease on two solid tumours in vivo. Nature 176: 36-37, 1955

20. Ardelt W, Mikulski SM and Shogen K: Amino acid sequence of an anti-tumor protein from Rana pipiens oocytes and early embryos. Homology to pancreatic ribonucleases. J Biol Chem 266: 245-251, 1991 .

21. Ledoux L and Revell SH: Action of ribonuclease on neoplastic growth. I. Chemical aspects of normal tumour growth: the Landschutz ascites tumour. Biochim Biophys Acta 18: 416-426, 1955.

22. Aleksandrowicz J, Urbanczyk J, Ostrowska A and Sierko J: Further research on the activity of ribonucleases in the blood and urine of patients suffering from proliferative hemocytopathia. Blood 13: 652-664, 1958.

23. Vert A, Castro J, Ruiz-Martinez S, Tubert P, Escribano D, Ribo M, Vilanova M and Benito A: Generation of new cytotoxic human ribonuclease variants directed to the nucleus. Mol Pharm 9: 2894-2902, 2012.

24. Fang EF and Ng TB: Ribonucleases of different origins with a wide spectrum of medicinal applications. Biochim Biophys Acta 1815: 65-74, 2011.

25. Castro J, Ribo M, Navarro S, Nogues MV, Vilanova $M$ and Benito A: A human ribonuclease induces apoptosis associated with $\mathrm{p} 21 \mathrm{~W}^{\mathrm{AF} 1 / \mathrm{CIP} 1}$ induction and JNK inactivation. BMC Cancer 11: 9,2011.

26. Kawauchi H, Sakakibara F and Watanabe K: Agglutinins of frog eggs: a new class of proteins causing preferential agglutination of tumor cells. Experientia 31: 364-365, 1975.

27. Sakakibara F, Kawauchi H, Takayanagi G and Ise H: Egg lectin of Rana japonica and its receptor glycoprotein of Ehrlich tumor cells. Cancer Res 39: 1347-1352, 1979.

28. Nitta K, Takayanagi G, Kawauchi $\mathrm{H}$ and Hakomori S: Isolation and characterization of Rana catesbeiana lectin and demonstration of the lectin-binding glycoprotein of rodent and human tumor cell membranes. Cancer Res 47: 4877-4883, 1987. 
29. Titani K, Takio K, Kuwada M, Nitta K, Sakakibara F, Kawauchi H, Takayanagi $\mathrm{G}$ and Hakomori S: Amino acid sequence of sialic acid binding lectin from frog (Rana catesbeiana) eggs. Biochemistry 26: 2189-2194, 1987.

30. Kamiya Y, Oyama F, Oyama R, Sakakibara F, Nitta K, Kawauchi H, Takayanagi Y and Titani K: Amino acid sequence of a lectin from Japanese frog (Rana japonica) eggs. J Biochem 108: 139-143, 1990.

31. Nitta K, Oyama F, Oyama R, Sekiguchi K, Kawauchi H, Takayanagi Y, Hakomori S and Titani K: Ribonuclease activity of sialic acid-binding lectin from Rana catesbeiana eggs. Glycobiology 3: 37-45, 1993.

32. Okabe Y, Katayama N, Iwama M, Watanabe H, Ohgi K, Irie M, Nitta K, Kawauchi H, Takayanagi Y, Oyama F, et al: Comparative base specificity, stability, and lectin activity of two lectins from eggs of Rana catesbeiana and $R$. japonica and liver ribonuclease from R. catesbeiana. J Biochem 109: 786-790, 1991

33. Nitta K, Ozaki K, Ishikawa M, Furusawa S, Hosono M, Kawauchi H, Sasaki K, Takayanagi Y, Tsuiki S and Hakomori S Inhibition of cell proliferation by Rana catesbeiana and Rana japonica lectins belonging to the ribonuclease superfamily. Cancer Res 54: 920-927, 1994.

34. Nitta K, Ozaki K, Tsukamoto Y, Furusawa S, Ohkubo Y, Takimoto H, Murata R, Hosono M, Hikichi N, Sasaki K, et al: Characterization of a Rana catesbeiana lectin-resistant mutant of leukemia P388 cells. Cancer Res 54: 928-934, 1994.

35. Nitta K, Ozaki K, Tsukamoto Y, Hosono M, Ogawakonno Y, Kawauchi H, Takayanagi Y, Tsuiki S and Hakomori S: Catalytic lectin (leczyme) from bullfrog (Rana catesbeiana) eggs. Int J Oncol 9: 19-23, 1996.

36. Liao YD: A pyrimidine-guanine sequence-specific ribonuclease from Rana catesbeiana (bullfrog) oocytes. Nucleic Acids Res 20: 1371-1377, 1992

37. Liao YD, Huang HC, Leu YJ, Wei CW, Tang PC and Wang SC: Purification and cloning of cytotoxic ribonucleases from Rana catesbeiana (bullfrog). Nucleic Acids Res 28: 4097 4104, 2000.

38. Tang $\mathrm{CH}, \mathrm{Hu} \mathrm{CC}$, Wei CW and Wang JJ: Synergism of Rana catesbeiana ribonuclease And IFN-gamma triggers distinct death machineries in different human cancer cells. FEBS Lett 579: 265-270, 2005.

39. Ishiyama M, Miyazono Y, Sasamoto K, Ohkura Y and Ueno K: A highly water-soluble disulfonated tetrazolium salt as a chromogenic indicator for NADH as well as cell viability. Talanta 44 1299-1305, 1997.

40. Liao YD, Huang HC, Chan HJ and Kuo SJ: Large-scale preparation of a ribonuclease from Rana catesbeiana (bullfrog) oocytes and characterization of its specific cytotoxic activity against tumor cells. Protein Expr Purif 7: 194-202, 1996.

41. Hu CC, Lee YH, Tang CH, Cheng JT and Wang JJ: Synergistic cytotoxicity of Rana catesbeiana ribonuclease And IFN-gamma on hepatoma cells. Biochem Biophys Res Commun 280: 1229-1236, 2001

42. Thomas $\mathrm{H}$ and Coley HM: Overcoming multidrug resistance in cancer: an update on the clinical strategy of inhibiting P-glycoprotein. Cancer Control 10: 159-165, 2003.

43. Ambudkar SV, Dey S, Hrycyna CA, Ramachandra M, Pastan I and Gottesman MM: Biochemical, cellular, and pharmacological aspects of the multidrug transporter. Annu Rev Pharmacol Toxicol 39: 361-398, 1999 .

44. Krishna $\mathrm{R}$ and Mayer LD: Multidrug resistance (MDR) in cancer. Mechanisms, reversal using modulators of MDR and the role of MDR modulators in influencing the pharmacokinetics of anticancer drugs. Eur J Pharm Sci 11: 265-283, 2000.

45. Stavrovskaya AA: Cellular mechanisms of multidrug resistance of tumor cells. Biochemistry (Mosc) 65: 95-106, 2000.

46. Ozben T: Mechanisms and strategies to overcome multiple drug resistance in cancer. FEBS Lett 580: 2903-2909, 2006.

47. Castro J, Ribo M, Puig T, Colomer R, Vilanova M and Benito A: A cytotoxic ribonuclease reduces the expression level of P-glycoprotein in multidrug-resistant cell lines. Invest New Drugs 30: 880-888, 2012
48. Elmore S: Apoptosis: a review of programmed cell death. Toxicol Pathol 35: 495-516, 2007.

49. Grutter MG: Caspases: key players in programmed cell death Curr Opin Struct Biol 10: 649-655, 2000

50. Mansouri A, Ridgway LD, Korapati AL, Zhang Q, Tian L, Wang Y, Siddik ZH, Mills GB and Claret FX: Sustained activation of JNK/p38 MAPK pathways in response to cisplatin leads to Fas ligand induction and cell death in ovarian carcinoma cells. J Biol Chem 278: 19245-19256, 2003.

51. Bunyard P, Handley M, Pollara G, Rutault K, Wood I, Chaudry M, Alderman C, Foreman J, Katz DR and Chain BM: Ribotoxic stress activates p38 and JNK kinases and modulates the antigenpresenting activity of dendritic cells. Mol Immunol 39: 815-827, 2003.

52. He K, Zhou HR and Pestka JJ: Mechanisms for ribotoxin-induced ribosomal RNA cleavage. Toxicol Appl Pharmacol 265: 10-18, 2012.

53. Iordanov MS, Wong J, Newton DL, Rybak SM, Bright RK, Flavell RA, Davis RJ and Magun BE: Differential requirement for the stress-activated protein kinase/c-Jun NH(2)-terminal kinase in RNA damage-induced apoptosis in primary and in immortalized fibroblasts. Mol Cell Biol Res Commun 4: 122-128, 2000.

54. Fang EF, Zhang CZ, Zhang L, Fong WP and Ng TB: In vitro and in vivo anticarcinogenic effects of RNase MC2, a ribonuclease isolated from dietary bitter gourd, toward human liver cancer cells. Int J Biochem Cell Biol 44: 1351-1360, 2012.

55. Dasmahapatra G, Lembersky D, Kramer L, Fisher RI, Friedberg J, Dent $\mathrm{P}$ and Grant S: The pan-HDAC inhibitor vorinostat potentiates the activity of the proteasome inhibitor carfilzomib in human DLBCL cells in vitro and in vivo. Blood 115: 4478-4487, 2010.

56. Chen J, Rusnak M, Luedtke RR and Sidhu A: D1 dopamine receptor mediates dopamine-induced cytotoxicity via the ERK signal cascade. J Biol Chem 279: 39317-39330, 2004.

57. Wilhelm SM, Carter C, Tang L, Wilkie D, McNabola A, Rong H, Chen C, Zhang X, Vincent P, McHugh M, Cao Y, Shujath J, Gawlak S, Eveleigh D, Rowley B, Liu L, Adnane L, Lynch M, Auclair D, Taylor I, Gedrich R, Voznesensky A, Riedl B, Post LE, Bollag G and Trail PA: BAY 43-9006 exhibits broad spectrum oral antitumor activity and targets the RAF/MEK/ERK pathway and receptor tyrosine kinases involved in tumor progression and angiogenesis. Cancer Res 64: 7099-7109, 2004.

58. Wolf BB and Green DR: Suicidal tendencies: apoptotic cell death by caspase family proteinases. J Biol Chem 274: 20049-20052, 1999.

59. Kuwana T, Smith JJ, Muzio M, Dixit V, Newmeyer DD and Kornbluth S: Apoptosis induction by caspase- 8 is amplified through the mitochondrial release of cytochrome $c$. J Biol Chem 273: 16589-16594, 1998

60. Li H, Zhu H, Xu CJ and Yuan J: Cleavage of BID by caspase 8 mediates the mitochondrial damage in the Fas pathway of apoptosis. Cell 94: 491-501, 1998.

61. Luo X, Budihardjo I, Zou H, Slaughter C and Wang X: Bid, a $\mathrm{Bcl} 2$ interacting protein, mediates cytochrome $c$ release from mitochondria in response to activation of cell surface death receptors. Cell 94: 481-490, 1998.

62. Schendel SL, Azimov R, Pawlowski K, Godzik A, Kagan BL and Reed JC: Ion channel activity of the BH3 only Bcl-2 family member, BID. J Biol Chem 274: 21932-21936, 1999.

63. Wei MC, Zong WX, Cheng EH, Lindsten T, Panoutsakopoulou V, Ross AJ, Roth KA, MacGregor GR, Thompson CB and Korsmeyer SJ: Proapoptotic BAX and BAK: a requisite gateway to mitochondrial dysfunction and death. Science 292: 727-730, 2001.

64. Viswanath V, Wu Y, Boonplueang R, Chen S, Stevenson FF, Yantiri F, Yang L, Beal MF and Andersen JK: Caspase-9 activation results in downstream caspase- 8 activation and bid cleavage in 1-methyl-4-phenyl-1,2,3,6-tetrahydropyridine-induced Parkinson's disease. J Neurosci 21: 9519-9528, 2001. 